\title{
14 \\ FORMATION OF A DIVERSIFIED MINING COMPANY
}

Renison Goldfields Consolidated Limited (RGC) came into existence as a majority owned Australian mining company on 27 July 1981. Max Roberts was the executive chairman. The company's shareholder base through to 1989 included Consolidated Gold Fields, initially at 49 per cent. The boards of the previous companies were disbanded and the board of the new company included three representatives from its major shareholder, as well as previous non-executive directors of Consolidated Gold Fields Australia (CGFA). ${ }^{1}$ Naturalisation status was granted on 19 May 1982. This required at least 51 per cent Australian

1 In the 1982 financial year, the company's first full year, RGC had three Consolidated Gold Fields' directors: RIJ Agnew, group chief executive and deputy chairman (and chairman-designate); ME Beckett, executive director; and AP Hichens, managing director-finance. Sidney Segal, former chairman of CGFA, was a director, along with Bart Ryan, the former managing director. Both retired at the end of 1982. The other independent directors were GM Niall, director of CGFA since its flotation in 1966; J Darling, who had joined the board in 1974; ES Owens, former chairman of Associated Minerals Consolidated and director of CGFA since 1977; and K Wood, previously a director of Renison and Mount Lyell. Apart from Roberts, three other executive directors were represented on the board: WP Murphy, formerly chief executive of Tennant Trading; LW Skelton; and BE Wauchope; while AD Hemingway, a member of RGC's executive committee, attended and participated in all board meetings. Hemingway, as general counsel and general manager of corporate affairs, had one of the most extensive levels of involvement in the evolution of CGFA and RGC. At his final board meeting in June 1990, it was recorded: 'The Chairman thanked Mr A. D. Hemingway for his great dedication to RGC and its predecessor, C.G.F.A. Mr Hemingway's wisdom, commitment and advice were of significant benefit to the Group'. A London-based director also expressed the appreciation of Consolidated Gold Fields for Hemingway's assistance, 'particularly during the period of Minorco's bid for CGF' (Renison Goldfields Consolidated Limited, 'Minutes of Meeting of Directors', 28 June 1990, Renison Goldfields Consolidated Archives, Box 11329, BRD 38/04). 
shareholding, the majority of the directors to be Australian citizens and an understanding by the Australian board that independence from its principal foreign shareholder would be assured. In the view of the chairman, naturalised status would 'be zealously guarded' and provide the new entity with greater flexibility to pursue its business aspirations. ${ }^{2}$ In fact, after Hanson became the major shareholder in 1989, it sought successfully to overturn the naturalised status of RGC in 1993 and appoint its own executive chairman. This would be a matter of considerable board discussion and conflict between the independent directors and Hanson's London chairman and management.

Expectations for the new company and its role in the Australian resources sector were high. Free of the need to seek increased Australian ownership via joint ventures or Foreign Investment Review Board approvals, RGC saw its growth in Australian and in overseas jurisdictions as occurring through exploration, project development, acquisitions and, where appropriate, diversification into other commodities. It also expected to gain the benefits from direct ownership and management of its main businesses. The newly formed RGC initially had three fully owned main subsidiaries-Renison, Mount Lyell and Associated Minerals Consolidated (AMC). These were later formed into separate divisions: tin, with Koba Tin acquired in 1988; copper; mineral sands; and a gold division including New Guinea Goldfields, Pine Creek, Lucky Draw and Porgera from 1990. RGC also reported upon its trading and marketing activities through Tennant Trading, which was acquired from Consolidated Gold Fields in 1982. An investment division was formed in 1984 and from 1993 Narama coal came into operation. ${ }^{3}$

Within the portfolio were remnants of CGFA's portfolio. These included Colinas, the primary production entity with interests in afforestation and cattle grazing near Kempsey, New South Wales. A 70 per cent interest was retained in the Gunpowder joint venture, now held within Circular Quay Holdings, while a 50 per cent interest was maintained with Dalgety Australia in the Glendell joint venture. This Hunter valley coal project represented the main opportunity for the group to re-enter the coal sector after the divestment of Bellambi, although other coal opportunities were considered,

2 Renison Goldfields Consolidated Limited, 'Report on the 1981 Financial Year', p. 3. RGC lost its naturalised status in 1993, when Hanson made application to the Foreign Investment Review Board for changes to director and chairman appointment arrangements, which had the effect of nullifying the naturalisation status.

3 The reference in this chapter is to financial years, ending 30 June. 
including the acquisition of an interest in the Blair Athol coal deposits in the Bowen Basin, Queensland, and the development of steaming coal resources at Eneabba in Western Australia. Neither eventuated. The project to develop the Glendell leases proved a protracted and frustrating process for the company. In the end, only a proportion of the lease area available to RGC was developed through the Narama operation.

A key component of the envisaged growth of the group was through Gold Fields Exploration, responsible for the exploration activities of the company in Australia and the region. This was an entity in which the London parent had an indirect interest, with funding of exploration activity partially reimbursed by Consolidated Gold Fields. The arrangement was established in 1979 and existed until 1984 when RGC took full responsibility for its exploration activities. A marine aggregate project off the coast of New South Wales was evaluated at the instigation of Consolidated Gold Fields in an association with its subsidiary company ARC Marine. This project planned to undertake dredging of sand and gravel off the coast, including at Broken Bay at the entry of the Hawkesbury River, north of Sydney. The lack of support by regulators for a contentious environmental activity meant that it did not progress.

While the formation of RGC as an Australian mining company presented the opportunity to transform the existing portfolio, its evolution over the next decade and a half was influenced to a large extent by the three main pillars of its asset base: AMC, Renison and Mount Lyell. In 1981, the funds employed were represented as mineral sands 45 per cent, tin 25 per cent, copper 10 per cent, and gold and other investments 20 per cent. In the 1997 financial year, the last year in which the company issued financial accounts, the assets employed were mineral sands 48 per cent; gold 38 per cent; tin 10 per cent; and coal, other base metals and a small copper exposure, 4 per cent. ${ }^{4}$

While RGC held bold aspirations, management and the board of RGC had an appreciation of the inherent constraints of the portfolio. Challenges were evident in the company's first years, most notably through to 1987 , associated with poor market conditions and pricing outcomes, particularly for mineral sands and copper, as well as the maturity and

4 In the intervening period, Mount Lyell and its copper production contribution had been closed and sold; the asset values at Renison had been reduced while gold assets had increased, reflected by RGC's 55.8 per cent interest in Goldfields Limited (Renison Goldfields Consolidated Limited, Annual Report 1997, pp. 27-30 and 57). 
operational challenges of Mount Lyell and commissioning issues for the Eneabba mineral sands operation. The characteristics of the portfolio, and the difficulties created by market conditions, dominated the early life of RGC. RGC's financial performance was weak during 1982 to 1984 and, while improving in 1985 and 1986, it was only from 1987 that the financial performance could be considered adequate, with a contribution from new operations. What followed in 1989 and 1990 were two of the company's strongest years in financial terms. ${ }^{5}$

In the early 1980s, Renison was the highest-quality asset in the portfolio. As the world's largest underground tin mine, it had been the major earnings contributor to CGFA in the years leading to RGC's formation. Its contribution continued, although in the first half of the 1980s, the International Tin Council imposed restrictions on tin production, which in turn produced inefficiencies in the unit costs of production and a lower level of tin sales. There followed the collapse of the tin buffer system in 1985 and a decline in the tin price. Operationally, the industrial relations climate at Renison, often fractious, worsened. Renison's financial contribution peaked in 1980 and then steadily declined (see Chart 10, Chapter 8).

Mount Lyell was in its 87 th year of operation in 1981. While accessing deeper ore reserves offered the opportunity to extend the life of the operation, low copper prices and the inability to offset this decline with lower costs meant that Mount Lyell was the most problematical asset in the RGC portfolio. In 1981 and 1982, Mount Lyell was viewed as in a crisis situation. Copper prices were the lowest in real terms for four decades, creating a cash deficit that meant that 'the Company's survival ... [was] at risk'. ${ }^{6}$ In 1982, the operation was closed temporarily. A long-term planning exercise resulted in the decision to proceed to mining deeper horizons, with work recommencing on the underground crushing and hoisting project, accessing the 30 and 40 series ore bodies and subsequently developing the 50 and 60 series. $^{7}$

5 See Appendix 4. RGC recorded successive profit increases from 1983 to 1987. In 1987 a return on shareholders' funds above 20 per cent was achieved and return on assets of 10 per cent. In the 1986 financial year, a new gold mining operation, Pine Creek, made a financial contribution and unlike the previous year there were no extraordinary items recorded in the reported results.

6 The Mount Lyell Mining and Railway Company Limited, 'Minutes of Committee Meeting', 28 May 1982, p. 6, National Archives of Australia, Tasmania (NAAT), NS3924, Items 288-295.

7 The Mount Lyell Mining and Railway Company Limited, 'Long Term Mining Plan, Progress Report-November 1982', NAAT, NS3357/1/105. In 1982, mining from the 30 series was nearing completion with mining of the 40 series planned, supplemented by satellite mining from Cape Horn. Drilling evaluation also occurred for the 50 and 60 series ore bodies, later to be mined. 
The AMC mineral sands assets were, by 1981, based at Capel and the newly acquired province of Eneabba in the north of Western Australia, along with a dredging operation at Green Cove Springs, Florida. The east coast operations had predominantly been closed, while RGC's mining and processing operations on North Stradbroke Island ceased in 1985. Prospects for mining leases on Moreton Island remained but, due to environmental opposition to mineral sands mining on Fraser Island, the likelihood of this occurring remained slight. The opportunity was extinguished by Commonwealth Government restrictions on issuing export licences for mineral sands mining. The company was also operating two synthetic rutile kilns, developed as a result of the technical advances by Western Titanium. Production capacity was expanded by the construction of a third kiln, as well as the development of a new form of synthetic rutile in an attempt to resolve the issue of high levels of radiation in some of the Eneabba ilmenites. Mineral sands exploration success stands out as a high point of RGC's exploration activities, with new provinces identified in the United States and in the Murray Basin of Victoria. While mineral sands remained a core part of the portfolio, it created frequent challenges in terms of financial performance. Mineral sands enjoyed periods of strong financial performance, but also extended periods of low returns.

In 1989, a fundamental change in the shareholder base of RGC occurred when Hanson Plc acquired Consolidated Gold Fields in the United Kingdom. Its motivations were in part opportunistic but also motivated by a desire to gain control of the Amey Roadstone business within the Consolidated Gold Fields' portfolio. The acquisition followed an unsuccessful takeover attempt by Minorco, an Anglo American affiliated company, which RGC management was active in assisting its parent to defend against.

With Hanson gaining control of Consolidated Gold Fields in the second half of 1989, it became the largest shareholder of RGC; with this a new dynamic emerged for the RGC board and management. Hanson's shareholding was associated with an initial year of strong RGC financial performance in 1990, followed by four poor years, including two that were loss-making, before a recovery in reported profits in 1995 and 1996, and then a loss in 1997, in large part due to the effects of asset write-downs associated with prior year investments (see Charts 5 and 6). Hanson's shareholding, board and subsequent management representation had a major influence on the fate of RGC as an independent, diversified mining company in Australia. 


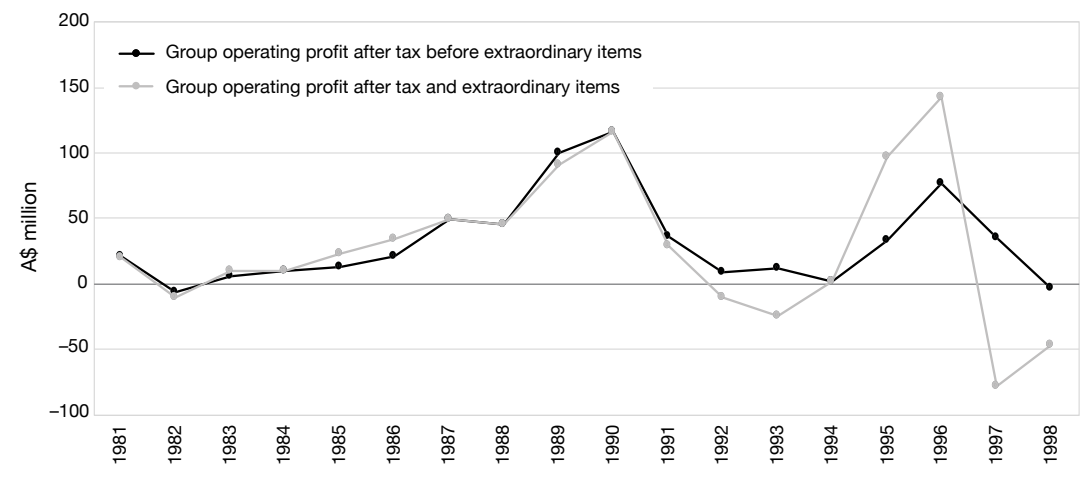

\section{Chart 5. Renison Goldfields Consolidated net profit/loss, 1981-1998.}

This chart shows RGC's profitability from 1981 to 1998. Extraordinary items influenced results in a number of years. See Appendix 4 for details of extraordinary items. Average operating profit after tax before extraordinary items was $\$ 27.9$ million. Average operating profit after tax and extraordinary items was $\$ 31.0$ million.

Sources: RGC annual reports, 1990 to 1997 . 1998 data for period to 30 June is derived from 'Information Memorandum in Relation to a Recommended Merger by Scheme of Arrangement between RGC Limited and Westralian Sands', pp. 34 and 56-57. Financial information for this year includes RGC's interest in Goldfields.

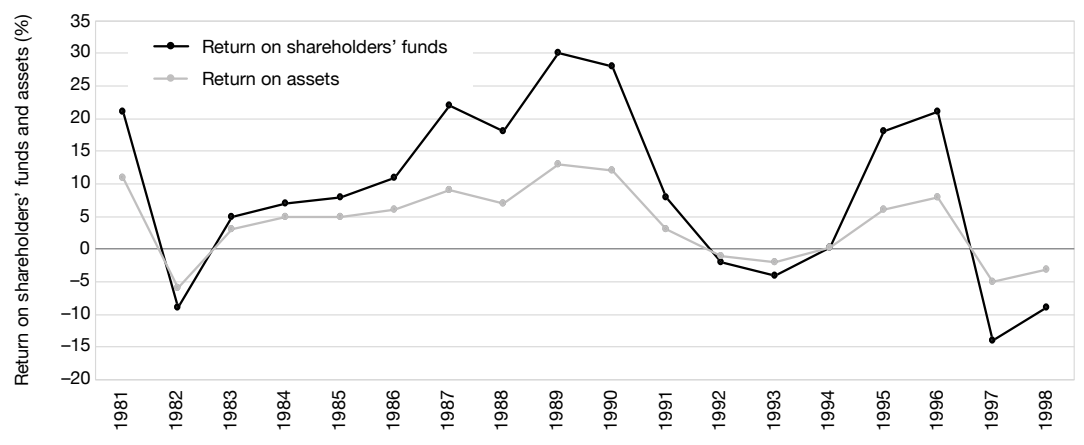

\section{Chart 6. Renison Goldfields Consolidated returns on shareholders' funds and assets, 1981-1998.}

This chart shows RGC's returns on shareholders' funds and assets, after extraordinary items, over the period 1981 to 1998 . Average return on shareholders' funds was 8.9 per cent and return on assets averaged 3.9 per cent over this 18-year period.

Sources: RGC annual reports, 1990 to 1997, and 'Information Memorandum in Relation to a Recommended Merger by Scheme of Arrangement between RGC Limited and Westralian Sands', pp. 34 and 56-57. 
RGC's approach to the management and growth of its portfolio had a number of consistent elements. Exploration remained a cornerstone. RGC maintained a well-resourced and technically competent exploration team, which in the mid-1980s included 50 geoscientists. Part of the exploration team was located in Canberra so as to be close to national geophysical data, with offices also in Darwin, Perth and the Philippines. Exploration expenditure increased every year from 1981, with the exception of 1991 and 1992, when under straitened financial circumstances and the scrutiny of the new major shareholder, budgets were trimmed. Even so, Hanson was prepared to support a large increase in exploration expenditure in its final two years of its shareholding in RGC. ${ }^{8}$

Exploration occurred in Australia, Papua New Guinea, the Philippines, the United States, Europe, and other jurisdictions. A ranking or prioritisation of minerals was adopted, with efforts directed to both the extension of the resource and reserve base of existing operations, which included Renison, Mount Lyell and Eneabba, as well as seeking new mineral provinces and deposits. RGC's exploration activities led to the development of two smaller Australian gold mines, as well as mineral sands deposits in the United States, and the opening up of the Murray Basin mineral sands province in Australia. Through its support for the listing of oil and gas exploration company, Minora Resources, RGC had an indirect involvement in exploration activities in the energy field. ${ }^{9}$ Project development activities were undertaken, which included the Pine Creek, Lucky Draw and Henty gold mines, the Eneabba West development, Old Hickory, the expansion of the Koba Tin operation, as well as a contribution to the determination of the form of ore processing adopted at Porgera.

Acquisition activity formed an important element of the company's approach. Several company acquisitions were considered. In mineral sands, RGC undertook the final aggregation of the Eneabba deposits by the acquisition of DuPont's stake in Allied Eneabba in 1985, following the prior acquisition of the Jennings Industries assets, gaining overall control of this major mineral sands province. In 1996, the acquisition of Cudgen RZ provided RGC with control of Consolidated Rutile Limited and its mining activities on North Stradbroke Island, as well

8 Exploration expenditure in 1996 and 1997 was \$43.3 million and \$50.5 million, respectively. In the previous five years it had averaged $\$ 21.8$ million.

9 Minora merged with Discovery Petroleum NL in 1994 with RGC retaining an interest. 
as its 50 per cent interest in the Sierra Rutile mineral sands operation in Sierra Leone, then not in production due to a civil war. Numerous other mineral sands acquisition opportunities were considered, although not progressed or not successful. The company's tin production base was expanded by the takeover in 1988 of the CSR and Boral interests in an Indonesian tin mining company, PT Koba Tin. Acquisitions to establish a presence in new commodities included a review of the Blair Athol coal deposits in the Bowen Basin, Queensland, with an approach made to ARCO Coal Australia. Consideration was given to acquiring the Cerro Corona gold and copper deposit in Peru, while other company acquisition opportunities evaluated, although not advanced, included North Broken Hill and Mount Isa Mines.

The establishment of an investment division occurred in 1984, viewed as a way to generate trading profits on share investments, as well as establish strategic holdings as a potential precursor to acquisition or merger activity. Tennant Trading acted as a source of revenue generation through commodity trading and marketing with, at one stage, over 65 per cent of its revenue generated from non-RGC derived businesses.

Corporate restructuring initiatives were considered. The most notable was the establishment in 1995 of a separate gold company, Goldfields Limited, to house RGC's gold interests and mount a takeover of Pancontinental Mining to acquire its gold assets, with the non-gold assets either acquired by RGC or sold. This transaction was finalised in 1996, although RGC was not successful in obtaining sufficient shareholder support to proceed to compulsory acquisition of all of the shares in Pancontinental Mining, an impediment it also encountered with the Cudgen RZ acquisition. A proposal by RGC in the late 1980s to acquire the 70 per cent interest in Mount Goldsworthy held by Consolidated Gold Fields was not successful when Hanson, as the new owner of Consolidated Gold Fields, sold the interest to BHP.

Hanson, as the major shareholder from 1989 to 1998, had little commitment to a diversified mining company model and minimal experience of mining. As an industrial conglomerate it typically held a much shorter time horizon for a return on capital from its investments than that employed by the RGC board and management. Disquiet by Hanson at the financial performance of RGC and the structure of the portfolio was evident from an early stage of its shareholding. While RGC management and Hanson investigated various means by which 
the Hanson shareholding could be sold to other parties, none eventuated until 1998. While Hanson can be considered to have exercised patience with its investment in RGC over nine years, this patience reached its limit, in part influenced by a patchy record of financial returns from its coincident investment in RGC, lack of confidence in the corporate management of the business and the emergence of yet another period of weak market conditions-particularly for mineral sands-requiring, in effect, a large capital requirement to replenish a portfolio of maturing assets. In addition, changes within the broader Hanson portfolio made the retention of a shareholding in an Australian diversified mining company even less logical.

In late 1992 and again in 1993, Hanson approached the Foreign Investment Review Board, without prior notification to the RGC board. The approaches reflected the malaise in the relationship between Hanson and the non-Hanson RGC directors and senior management. Hanson, in effect, sought the ability to appoint its own executive chairman, purportedly as a basis for growing its interests in Australia and the Pacific Rim region, but essentially to exert more management and financial control. For the non-Hanson RGC directors, it was seen as a covert attempt to take over the company without the payment of a premium and proceed with the further dismemberment of the RGC diversified portfolio. Hanson's overtures, despite vigorous opposition from RGC's chairman and managing director, resulted in overturning the naturalised status of RGC, in management change and, in turn, a Hanson-appointed candidate selected as deputy chairman, to become chairman within a year. Further management change followed and, in 1998, the Hanson-appointed chairman assumed dual executive and chairmanship responsibilities.

The instability within RGC played into the hands of the managing director of Westralian Sands, Malcolm Macpherson. He made an approach to Hanson in London in 1998 and proposed a combination of the two companies. By July 1998 there was a merger implementation agreement and in December of that year RGC held its final board meeting at Gold Fields House, Circular Quay, Sydney. Six RGC directors resigned and six Westralian Sands directors were appointed to the new entity that initially took the name Westralian Sands. ${ }^{10}$ Macpherson became the managing

10 The name was changed to Iluka Resources in 1999. 
director of the new merged entity. Only one former RGC executive was represented on the executive of the new company. The corporate head office of RGC in Sydney was closed and most of the corporate staff dismissed. Hanson shortly thereafter exited its shareholding.

Westralian Sands exerted management and board control, and undertook the almost complete rationalisation of the RGC non-mineral sands assets. ${ }^{11}$ As such, RGC ceased to exist either in name or in terms of the continuity of a diversified mining portfolio. A company with a pedigree, through Consolidated Gold Fields, stretching back over 100 years and with a direct involvement in Australia for over 70 years, including 38 years as an Australian diversified mining company, had reached the end of its existence. It was an underwhelming conclusion for a company with such a proud heritage in the global mining industry.

The following chapters will describe the main elements of the management of the RGC portfolio from 1981 to 1989; the events leading to the takeover of Consolidated Gold Fields by Hanson, and the final years of RGC's existence before its merger with Westralian Sands in 1998.

11 The exceptions were Narama coal and the Mining Area C royalty entitlement, which did not contribute financially until 2003, after the formation of Iluka Resources, when BHP began production from Area C. 
This text is taken from Consolidated Gold Fields in Australia: The Rise and Decline of a British Mining House, 1926-1998, by Robert Porter, published 2020 by ANU Press, The Australian National University,

Canberra, Australia.

doi.org/10.22459/CGFA.2020.14 